\title{
Kadın Girişimcilere Ait İşletmelerin Marka Yaratım ve İletişim Süreçlerinde Sosyal Medyanın Yeri
}

Ebru GÖKALILER*

Özlem ALIKILIÇ**

\section{Özet}

$\mathrm{Bu}$ çalışmada kadın girişimcilerin sosyal medyada aktif bireysel paylaşımlarının yanında, iş geliştirme ve markalarının tanıtımında sosyal medyadan yararlanıp yararlanmadıkları rasyonelinden yola çıkılmıştır.

$\mathrm{Bu}$ çalışmada temel alınan konu, kendi işini kuran kadın girişimcilerin sosyal medya platformlarını kullanarak gerçekleştirdikleri marka yaratım çalışmalarının neler olduğu ve bu çabalarına ilişkin iletişim faaliyetlerinin saptanması amaçlanmaktadır. Bu bağlamda İzmir'de sosyal medyada en çok bilinen ve yararlı faaliyetlerde bulunan bir Yahoo haber grubu; İzmirli Anneler platformu üyeleriyle amaçsal örneklem metoduyla seçilen üyeler arasından içerik analizi çalışması gerçekleştirilmiş ve elde edilen veriler analiz edilmiştir. Çalışmada İzmirli kadın girişimcilerin Facebook'taki kurumsal sayfalarını aktif olarak kullanmadıkları ve marka iletişimi faaliyetlerinde hedef kitleleriyle çift yönlü ve periyodik ilişki kuramadıkları tespit edilmiştir. Bunun yanı sıra Facebook'taki kurumsal sayfalarının markalarına katkıları ve iletişim çalışmalarındaki yeri de bulgular ve sonuç kısmında değerlendirilmiştir.

Anahtar Kelimeler: Kadın Girişimciler, Sosyal Medya, Marka İletişimi, Facebook.

\section{The Role of Social Media in Communication and Branding Process of Woman Entrepreneurs' Companies}

\begin{abstract}
While Facebook has grown exponentially for enterpreneurs seeking new ways of connecting with their customers, woman enterpreneurs have increasingly used Facebook pages to create a brand or enhance their current

* Yrd. Doç. Dr., Yaşar Üniversitesi İletişim Fakültesi Halkla İlişkiler ve Reklamcilık Bölümü

** Yrd. Doç. Dr., Yaşar Üniversitesi İletişim Fakültesi Halkla İlişkiler ve Reklamcılık Bölümü
\end{abstract}


brands. This paper initiated an study on how local brands in Izmir employ social media, particularly Facebook, to increase brand communication and reinforce brand loyalty. Thus, the objective of the present study is to analyze the woman enterpreneurs' uses of Facebook to engage and interact with their target audiences including Facebook fans, consumers, and clients. Using content analysis, the Facebook pages of eight brands that were founded by woman enterpreneurs in Izmir were analyzed in terms of their frequency of communication with their target audiences, the types of engagement with them, and the degree of connectivity with their fans. In this context, this study represented findings from a content analysis of Facebook posts from eight companies which were founded by women to see what types of social media promotion tools were used to connect with their users. The study has shown that, although woman enterpreneurs have official corporate Facebook pages, they are lack of brand communications and lack of connecting with their customers and fans through their Facebook pages. In conclusion, contributions of brand communication through Facebook and the importancy of communication programs designed in Facebook were discussed.

Key Words: Women Entrepreneurs, Social Media, Brand Communication, Facebook.

\section{Giriş}

Bugün internet teknolojisinde yaşanan hızlı gelişmeler sadece toplumların yapısını değiştirmekle kalmamış, iş yapma yöntemlerini de geliştirmiştir. Yeni iş modelleri geliştirme, müşteri ilişkileri, e-ticaret gibi bilinen birçok iş yapış yöntemi, yerini sosyal medya üzerine kaydırmıştır. Sosyal medya doğası gereği özellikle işletme ve markalara aracı olmadan, hedef kitleleriyle doğrudan iletişim kurma fırsatı da sağlamıştır (Kuvykaite ve Piligrimiene, 2013). Bunun yanı sıra, işletmeler ve hedef kitleleri arasında oluşan doğrudan etkileşimler, marka yönetiminin işletmeden hedef kitleye doğru giden dikey boyutunu da değiştirmiş; hedef kitleden işletmeye, hedef kitle ile kitleler arasında da gerçekleşmeye başlamıştır. Marka yönetimi performansı bugün artık sosyal medyada marka etkileşimi ve olumlu, sürdürülebilir sohbetler yaratabilmekle değerlendirilmektedir.

İnternetin doğası ve bizlere sunduğu olanaklar sadece tüketiciler için geçerli değildir elbette. Ticaretin elektronik ortama kolaylıkla geçtiği bu süreçte, girişimcinin ve girişimciliğin de bu değişimden payını aldığ 1 tartışılmazdır. Girişimci en temel tanımıyla, daha çok kendi işini kuran, 
çeşitli üretim faktörlerini bir araya getirerek ve risk üstlenerek üretim sürecinde bulunan ve bunun sonucunda da kar elde etmeyi amaçlayan kişi olarak tanımlanmaktadır (Emsen, 1996: 154). Kadın girişimcileri tanımlayan nitelikler, dinamik, bağımsız, özgüvenli, rekabetçi ve amaç yönelimli olmalarıdır. Ayrıca girişimcilik faaliyetini sürdüren kadınlar hırslı olma, risk alma, kendi işini kontrol etme gibi özellikler çerçevesinde de betimlenmektedir (Yetim, 2002). Çelebi'ye (1997: 19) göre kadın girişimciler erkek girişimcilerle karşılaştırıldığında, aralarında benzerlikler bulunmasına rağmen kadın girişimciler erkek girişimcilerden daha farklı güdülere, iş hüneri düzeyine ve mesleki geçmişe sahiplerdir. Keza Hisrich ve Peter (1989) çalışmalarında kadına özgü ve erkeğe özgü olarak tanımlanabilecek işler konusunda çeşitli farklılıklar saptamışlardır. Örneğin erkek girişimcilerin üretim, inşaat gibi sektörleri seçerlerken, kadın girişimciler danışmanlık, eğitim, halkla ilişkiler gibi hizmet sektörünü tercih ettikleri görülmüsstür. Yetim ve Tatlıdil (2004) de benzer bulgulara değinerek, imalat sektöründe kadın girişimci oranının oldukça sınırlı kaldığın, ilaveten bu sektörde faaliyet gösteren kadınların da genellikle erkek ortaklarla birlikte çalıştıklarından bahsetmektedirler (Yetim ve Tatlıdil, 2004).

Hisrich ve Peter (1989) yaptıkları çalışmada demografik özellikler arasında "yaş" faktöründe de dikkat çekici bir bulguyu da paylaşmışlardır. Buna göre erkek girişimciler, genel olarak 25-35 yaş arasında ilk işlerini kurarken, kadın girişimciler bu potansiyele ancak 35-45 yaş arasında ulaşabilmektedir (s.66).

\section{Kadın Girişimciler}

Kadın girişimi ve kadın girişimciler dünya genelinde 1980'li yıllardan itibaren çok farklı disiplinlerin ilgi alanı haline gelmeye başlamıştır. Kadın girişimciler üzerine yapılan çalışmalar, genellikle kadınların sosyo-demografik özelliklerinin belirlenmesi, ne tür işler kurdukları, hangi motivasyonlar sonucu iş kurdukları, sosyal ve kültürel dinamikleri, işi kurma sırasında ve iş sürecinde karşılaştıkları sorunlar, erkek girişimcilerden farklılıkları gibi konular üzerine odaklanmaktadır (Yetim ve Tatlıdil, 2004; Ufuk ve Özgen, 2001; Emsen, 2001; Ertübey, 1993; Hisrich ve Peters, 1989; Hisrich ve Öztürk, 1999).

1980'li yıllar kadınların iş yaşamına katılımı açısından dönüm noktası olmuştur. Bu dönem içinde işgücüne katılan artarken, çalışan karıkoca sayısı yükselmiş ve ailenin geçimini tek başına sağlayan annelerin görülmesi sıklaşmıştır (Soysal, 2010: 85). Dünya ve Türkiye'de gelişen ve değişen toplumsal ve ekonomik yapı çalışan kadın sayısının da artmasına sebep olmuştur. Bu dönemden itibaren kadınların iş dünyasındaki varlığ 
artmıştır. Kadınların iş yaşamına katılmasına yönelik olan bu ilgi, özellikle gelişmekte olan ülkelerde benimsenen ihracata yönelik kalkınma stratejileri ile yakından ilişkili olduğu belirtilmektedir. (Özkaya, Erdem, 2009: 56) Günümüzde ise kadınların iş dünyasına katılım verileri incelendiğinde ortaya çok da parlak olmayan bir tablonun çıtı̆̆ı belirtilebilmektedir. TÜİK tarafından 2012 yılında Türkiye genelinde gerçekleştirilen "İstatistiklerle Kadın, 2012" Raporunda yer alan veriler incelendiğinde kadınların iş yaşamına erkeklerden daha az katıldığı tespit edilmiştir. 2012 yılında kadınların işgücüne katılım oranı sadece \%29.5 iken, erkeklerin \%71 oranındadır. Aynı araştırma kapsamında ücretli ya da yevmiyeli olarak çalışan kadınların oranı \%54.3 iken kendi hesabına çalışan kadınların oranının \%10.8 olduğu, ücretli veya yevmiyeli olarak çalışan erkeklerin oranının \%66.5, kendi hesabına çalışan erkeklerin oranının ise \%22.3 olduğu görülmektedir. ${ }^{1} \mathrm{Bu}$ bilgiler çerçevesinde kadınların iş yaşamına katılımının erkeklerden daha az olduğu söylenebilmektedir. Ancak günümüzde kadının ekonomi içindeki ağırlığının artması, bilgi iletişim teknolojilerinde yaşanan gelişmeler, artan üniversite sayısına paralel olarak kadının yükseköğrenim seviyesinin artması sonucunda kadınların kendi işlerini kurma girişimlerinin de buna paralel olarak arttığı söylenebilir.

Kadınların özellikle sosyal medyada aktif varlığı; onların içerik üretimini de aynı derecede önemli kılmıştır. Bugün sadece öğrenciler, ev kadınları değil kadın girişimciler de sosyal medyada aktif bir şekilde yer almaktadırlar.

\section{Sosyal Medyada Kadın Girişimciler}

Küresel araştırma şirketi TNS Global'in (2013) Türkiye'nin Kadın Omnibus araştırmasında, Türkiye'deki kadınların internet kullanım alışkanlıkları incelenmiştir. Araştırma sonuçlarına göre, Türkiye'deki kadınların en fazla Facebook'u kullandığı ortaya çıkmıştır. TNS Global'in araştırmasında kadınlara yöneltilen "En çok hangi siteyi ziyaret ediyorsunuz" sorusuna "Facebook" cevabı ilk sırada yer almıştır. Bu oran sadece Türkiye'de de değil, yurt dışında da benzerlikler göstermektedir. Örneğin Amerika Birleşik Devletleri'nde de yapılan benzer araştırmalar kadınların Facebook'u sadece arkadaşlarıyla bağ kurmak için değil, kurum ve markalarla da iletişim kurmak için kullandıklarını işaret etmektedir (Shen \& Bissel, 2013; Galloway, 2012). Girişimciler açısından da

1 İstatistiklerle Kadın, 2012, Türkiye İstatistik Kurumu Haber Bülteni, Sayı. 13458, http://www.tuik.gov.tr/PreHaberBultenleri.do?id=13458, Yayın Tarihi: 8 Mart 2013, Erişim Tarihi: 29.01.2014 
benzer yükselme görülebilmektedir. Sayısız girişimler ve markaların Facebook sayfaları açılmış ve pek çoğu da aktif olarak hedef kitleleriyle iletişimlerini sürdürmektedir. Bugün artık Facebook üzerinden mevcut ve potansiyel müşterileri ile iyi ilişkiler geliştirip yönetmek en önemli dijital pazarlama amacı haline gelmiştir (Shen \& Bissel, 2013).

Şüphesiz ki medya tüketimi geleneksel medyadan sosyal medyaya doğru hızlı bir şekilde kaymaya devam etmektedir. Bu yön değişikliği, ister istemez şirketleri ve markalarını da aynı yöne doğru yönlendirmiştir. Bugün artık şirketler ve markalar marka iletişimlerinde tüketicileri ile daha fazla sosyal medya üzerinden iletişim kurmaktadırlar. Eskiden ürün ve hizmetlere dair bilgiler tüketiciye aktarılırken, bugün sosyal medyanın doğasından ötürü, bilgiler sadece aktarılmayıp paylaşılmakta ve değiş tokuş edilmektedir. Bilindiği kadarıla bugüne kadar Türkiye'de kadın girişimcilerin sosyal medyada özellikle Facebook'ta hedef kitlesiyle nasıl marka iletişimi kurduğuna dair bir çalışma fazla yoktur. Var olan çalışmalar da genellikle kadınlara odaklanmaksızın, bir girişim sürecine bağlı olarak ortaya çıan markaların, sosyal medya üzerinden marka ve pazarlama iletişimlerini incelemeye yöneliklerdir (Algür ve Cengiz, 2011; Kara ve Coşkun, 2012).

Bugün Facebook sadece dünyada değil, Türkiye'de de hızlı bir şekilde büyürken, bireylerin sadece birbirleriyle bağlantı kurmasını (ve bağlantılı kalmasını) sağlamakla kalmamıştır. İlaveten, şirketler ve türlü girişimciler de Facebook'u kurumsal ve pazarlama amaçları doğrultusunda kullanmak adına önemli fırsatlar gördüler. Bu fırsatlar arasında marka yaratmak, marka iletişimini sürdürmek gibi önemli marka amaçları da bulunmaktaydı. Smith (2009), The Facebook Marketing adlı çalışmasında, Facebook'un marka mesajlarını hedef kitleye göndermede ve hedef kitleyi markaya çekmekte son derece başarılı olabileceğini belirtmiştir.

\section{Çevrimiçi İlişki Ekme Stratejileri}

Her geçen gün artan sosyal medya kullanımı sebebiyle, işletmeler iletişim çalışmalarında çevrimiçi stratejilere yönelmektedirler. Kullanım özellikleri ve yapısı nedeniyle Facebook ve Twitter'ın işletmelerin tüketicilerle çevrimiçi ilişki kurması açısından en uygun araç olduğu belirtilmektedir (Smith, 2010). Genel olarak değerlendirildiğinde; sosyal ağlar işletmeleri daha insancıl yapmakta, kişisel temas ile arkadaş yanlısı ve dost bir kurum haline gelmektedirler (Kent \& Taylor, 1998). İşletmeler tüketicilerle yakın ilişki kurarak bağ kurmakta ve çevrimiçi paylaşımlarla işletmenin dünyasını tüketicinin dünyasına yakınlaştırmaktadır. Bu süreç stratejik açıdan incelendiğinde; işletmelerin çevrimiçi ilişki yönetimi 
sürecinde sosyal ağları kullanarak nasıl tüketicilerle iletişim kuracaklarına dair ekme stratejisi geliştirilmiştir.

Bugüne kadar yapılmış olan çalışmalar incelendiğinde (Grunig \& Huang, 2000; Hung, 2006; Ki \& Hon, 2006; Canary \& Stafford, 1992), literatürde ekme (relationship cultivation) kuramına yönelik tüm strateji belirleme çalışmalarının, genellikle çevrimdışı (offline) ortamlara yönelik olduğu görülmektedir. Örneğin; olumluluk, açıklık, ağ kurma, görünen liderlik, cevap verebilme, meşruiyet, eğitime dayalı iletişim ve saygı duyma gibi (Men \& Tsai, 2012). Kent ve Taylor $(1998,2002)$ diyaloga dayalı iletişim teorisini ortaya attıklarında, ekme kuramını çevrimiçi ortamlara adapte etme fırsatını yakaladılar. Keza onlar da birçok çevrimdışı ilişki ekme stratejilerini inceleyerek, bu stratejileri çevrimiçi ortamların doğasına uyarladılar. Kent ve Taylor'un günümüze kadar gelen birçok çalışması (Kent \& Taylor, 1998; Kent \& Taylor, 2002; Kent, 2008), çevrimiçi ortamlarda nasıl ilişkilerin yetiştirilebileceğine ilişkindir. Men ve Tsai (2012) çalışmalarında Kent ve Taylor'un (1998; 2002; Kent, 2008) ve Canary ve Strafford'un çalışmalarından adapte ederek, internet üzerinden geliştirilebilecek üç temel çevrimiçi ekme stratejisi geliştirmişlerdir.

Ekme stratejisi kapsamında ilk strateji açılık stratejisidir. Açılık stratejisi; tüketicilerle işletme arasında doğrudan ve açık bir konuşma ortamı sağlanmasıdır. Sosyal ağlar aracılığıyla işletmeye ait bilgiler uygun bir biçimde belirtilmektedir. Waters vd (2009) bu konuyla ilgili olarak işletmenin kurumsal sosyal ağ sayfasında tam iş tanımını, tarihçesini, misyon, vizyon ve hedeflerini, kurum sitesine hiperlinklerle bağlantı verilmesini, kurumsal logo ve görsellerine yer verilmesini önermektedir. Böylece kurum ile ilgili tüketicinin aklında herhangi bir soruya yer kalmayacak şekilde bilgi akışı sağlanmakta ve işletmeye tüketicinin güvenini artması ve bağ kurulmasında destek olunmaktadır.

İkinci strateji bilgiyi yayma stratejisidir. Bu strateji; bilgiyi yayma, halkın ihtiyaçları, endişeleri ve ilgi alanlarıyla ilgili işletme çerçevesinde bilgi verme gibi konuları kapsamaktadır. Kent ve Taylor (1998) halka yönelik yapılan bu tür bilgi paylaşımının işletmeyle tüketici arasında yakınlık yaratacağını ve bilgi aktaran bir ortak olarak algılanacağını savunmaktadır. Sosyal ağlar aracılığıyla kurumun yüklendiği video, fotoğraf, duyuru gibi konular, basın bültenleri ve basında çıan haberler işletmenin bilgi yayma araçlarından bazılarıdır.

Üçüncü olarak interaktiflik ve ilginlik stratejisinde sosyal ağların yapısından kaynaklanan interaktiflik özelliği ile sosyal ağlar, tüketicilerle ilişki kurma sürecinde diğer çevrimiçi araçlardan daha etkili bir araç 
olmaktadır. McMillan, Hoy, Kim, and McMahan (2008) yaptıkları çalışmada internetin interaktifliğini insan-bilgisayar interaktifliği (örn: yönlendirme), insan-insan interaktifliği (örn: işletmeyle iletişim kurma fırsatı, arkadaşa önerme veya kendi sayfasında içeriği paylaşma), insan içerik interaktifliği (örn: işletmenini postlarına yorum yapma veya diğer postlara cevap verme) olmak üzere üç alanda sinıflandırmaktadır.

$\mathrm{Bu}$ bağlamda işletmeler, sosyal medya ağlarını kurumsal amaçla kullanma sürecinde tüketicilerle ekme stratejisi çerçevesinde çevrimiçi olarak bilgi paylaşarak işletme ile tüketici arasında bağ kurmaktadır.

\section{Facebook'ta Marka İletișimi}

Facebook'u marka iletişiminde kullanan şirketlerin yöntemleri arasında, öncelikle kurumsal sayfa oluşturma, grup oluşturma, beğeni (like) alma, reklam verme, sürekli içerik üretme, yeniden pazarlama (remarketing) uygulamaları, gelen yorumlara marka içerikleri üretme, viral videolar ve / veya audio'lar üretme ve uygulamalar bulunmaktadır.

$\mathrm{Bu}$ yöntemler Facebook'un kendi bünyesinde sunduğu marka iletişimi çalışmaları olmasına rağmen, Facebook'un uygulama geliştirmeye izin veren yazılımı sayesinde gün geçtikçe kullanıcılara daha fazla imkanlar sunmaktadır. Facebook'un özellikle girişimcilere yönelik sunmuş olduğu bu tür imkanlar sayesinde, küçük işletmeler de kendi iletişim çalışmalarını herhangi bir aracı kuruma ihtiyaç duymaksızın gerçekleştirmektedirler. Girişimcilerin kolaylıkla uygulayabilecekleri en basit marka iletişimi uygulamaları arasında; marka ve şirketlere hayran sayfaları oluşturma, kullanıcıların profil bilgilerine göre sayfasında reklam yayınlaması ve benzeri uygulamalar da bulunmaktadır (Shih, 2009).

Sadece küçük ve orta ölçekli şirketlerin değil, pek çok büyük markanın da Facebook'u aktif bir şekilde kullanmakta olduğu da bilinmektedir. Son yıllarda kadın girişimciler için önemli bir mecra haline gelen sosyal medya, markalarıyla tüketicilerin bir araya geldikleri, etkileşim içinde oldukları önemli bir mecra haline de gelmiştir. Sosyal medya iletişim stratejileri arasında iletişim amacı, hedef kitle, mesaj teması, içerik formatı ve sosyal medya kanalları yer almaktadır (Kuvykaite ve Piligrimiene, 2013: 307). Markalar tüketicileriyle bağ kurdukları alanlarda hedef kitleye yönelik iletişim çalışmalarının amaçlarını net olarak tespit ederek sosyal medya iletişimine başlamakta, mesajı tüketiciye özel üretmekte, mesaja uygun olarak oluşturdukları içerikleri arasında marka algısına yönelik paylaşımlarda bulunmaktadırlar. Seçtikleri sosyal medya kanalları da aynı şekilde hedef kitleye uygun olarak tercih edilmektedir. Bu süreç içinde girişimciler markalarını hedef kitlenin zihninde rakiplerinden 
farklılaştırmakta ve sosyal medya ile iletişim süreçlerini sürekli hale getirmektedirler.

\section{Araştırmanın Amacı}

Son yıllarda pek çok markanın markalaşma sürecinde ve iletişim çalışmalarında sosyal medya önemli bir rol oynamaktadır. Özellikle kadınların sosyal medyayı etkin kullanmaları ve içerik üretimlerindeki etkinliği dikkat çekmektedir. Kadın girişimciler de markalarıyla ilgili mesajlarının hedef kitleye iletilmesinde sosyal medyayı tercih etmektedirler. $\mathrm{Bu}$ çalışmanın amacında kadın girişimcilerin sosyal medyayı kullanarak markaları için neler yaptıkları ve bu çabalarına ilişkin iletişim faaliyetlerinin saptanması amaçlanmaktadır. Bu kapsamda, kadın girişimcilerin Facebook sayfaları üzerinden hedef kitleleriyle çevrimiçi ilişki kurup kurmadıkları incelenmiş ve ilişki kuruyorlarsa ağırlıklı olarak nasıl kurdukları araştırılmıştır. Ayrıca, kadın girişimcilerin hangi tür içerikleri daha fazla ürettikleri irdelenmiştir. Kadın girişimcilerin sosyal medya sayfalarında tüketicileriyle kurdukları iletişim tarzı da incelenmiştir.

\section{Araştırmanın Kapsam, Yöntem ve Sınırlılıkları}

Türkiye'de en çok takip edilen sosyal medya ağının Facebook olması nedeniyle araştırma kapsamında kadın girişimcilerin girişimlerine ait Facebook sayfaları içerik analizi yöntemiyle incelenmiştir.

Kadın girişimcilere ait bu sayfaların belirlenmesinde, amaçsal örneklem yöntemi kullanılarak, İzmir'de sosyal medyada aktif faaliyet gösteren ve temalı faaliyetlerde bulunan bir haber grubu "İzmirli Anneler platformu" seçilmiştir. Bu platformun araştırma evreni kapsamına alındığ araştırma öncesinde, kartopu örneklem yöntemiyle, kadın girişimciler belirlenmiştir. Bu bağlamda 8 kadın girişimciye ait markanın Facebook'taki resmi hesapları üzerinde içerik analizi yapılmıştır. Bu markalar;

- Zeytin Kostüm (https://www.facebook.com/zeytin.kostum)

- Süslü Kasap (https://wwww.facebook.com/SusluKasap2

- Kidolindo (https://www.facebook.com/Kidolindo)

- İdivino (https://www.facebook.com/idivy?fref=ts)

- Tortiera (https://www.facebook.com/tortiera)

- Shapes for Woman / Shapes Merkez

(https://www.facebook.com/shapesforwomen)

- Kurabiye Canavarı

(https://www.facebook.com/cansu.arslan.714?fref=ts7, 
https://www.facebook.com/groups/299918836771097/?fref=ts;

https://www.facebook.com/kurabiyecanavarisiparis)

- Bia Halkla İlişkiler ve Reklam

(https://www.facebook.com/\#!/BiaReklam?fref=ts)

olarak saptanmıştır.

Araştırma, 1 Mayıs 2013 ile 1 Mayıs 2014 tarihleri arasındaki bir yıllık sosyal medya içerik üretimlerini kapsamaktadır. İçerik analizi kapsamında kadın girişimcilerin girişimcilerine ait Facebook sayfaları; profil sayfası analizi, kurumsal sayfa geliştirme, içerik türü, kurumsal içerik konuları ve en popüler içerikler olarak kategorize edilerek incelenmiştir. İçerik analizi kapsamındaki kategorizasyon, Waters vd.'nin (2009) Engaging stakeholders through social networking adlı makalesi, Ginnosar (2008)' in Online participation: A content analysis of differences in utilization of two online cancer communities by men and women, patients and family members adlı makalesi ve Shen ve Bissel'in (2013) Social media, Social me makalesindeki ölçekler derlenerek oluşturulmuştur.

Araştırmanın kısıtları arasında zaman kısıtı nedeniyle tüm kadın girişimcilerin Facebook sayfalarının incelenememesi yer almaktadır. Ayrıca sadece tek bir sosyal medya aracının seçilerek diğer sosyal medya araçlarının incelenmemesi bir diğer kısıttır.

\section{Bulgular}

Tablo 1: İzmirli kadın girişimcilerin işletmelerine ait Facebook profil sayfası

\begin{tabular}{|c|c|c|c|c|c|c|c|c|}
\hline Profil sayfası & $\begin{array}{l}\text { Zeytin } \\
\text { Kostüm }\end{array}$ & $\begin{array}{l}\text { Süslü } \\
\text { Kasap }\end{array}$ & Kidolindo & İdivino & Tortiera & $\begin{array}{l}\text { Shapes } \\
\text { Merkez }\end{array}$ & $\begin{array}{l}\text { Kurabiye } \\
\text { Canavarı }\end{array}$ & $\begin{array}{l}\text { Bia } \\
\text { H.I..R. }\end{array}$ \\
\hline Kurum logosu & $\sqrt{ }$ & $\sqrt{ }$ & $\sqrt{ }$ & $\sqrt{ }$ & $\sqrt{ }$ & $\sqrt{ }$ & $x$ & $\sqrt{ }$ \\
\hline $\begin{array}{l}\text { Kurumsal } \\
\text { kapak } \\
\text { fotoğrafi }\end{array}$ & $\sqrt{ }$ & $\sqrt{ }$ & $\sqrt{ }$ & $x$ & $\sqrt{ }$ & $\sqrt{ }$ & $x$ & $x$ \\
\hline $\begin{array}{l}\text { Düzenli } \\
\text { durum } \\
\text { güncellemesi }\end{array}$ & $x$ & $\mathrm{x}$ & $\sqrt{ }$ & $\sqrt{ }$ & $\sqrt{ }$ & $\sqrt{ }$ & $x$ & $\sqrt{ }$ \\
\hline $\begin{array}{l}\text { Yoruma cevap } \\
\text { verme }\end{array}$ & $x$ & $x$ & $x$ & $x$ & $x$ & $x$ & $x$ & $x$ \\
\hline Link & $\sqrt{ }$ & $\sqrt{ }$ & $\sqrt{ }$ & $\sqrt{ }$ & $\sqrt{ }$ & $\sqrt{ }$ & $x$ & $\sqrt{ }$ \\
\hline İçerik üretimi & $\sqrt{ }$ & $\sqrt{ }$ & $\sqrt{ }$ & $\sqrt{ }$ & $\sqrt{ }$ & $\sqrt{ }$ & $\sqrt{ }$ & $\sqrt{ }$ \\
\hline $\begin{array}{l}\text { Beğeni / } \\
\text { Takipçi sayısı }\end{array}$ & $x$ & 2.611 & 2.177 & 157 & 1.397 & 3.579 & 129 & 1.463 \\
\hline $\begin{array}{l}\text { Aynı isimli } \\
\text { başka sayfa }\end{array}$ & $\sqrt{ }$ & $\sqrt{ }$ & $x$ & $\sqrt{ }$ & $\sqrt{ }$ & $\sqrt{ }$ & $\sqrt{ }$ & $\sqrt{ }$ \\
\hline F-ticaret & $\mathrm{X}$ & $\sqrt{ }$ & $x$ & $x$ & $x$ & $\mathrm{X}$ & $\sqrt{ }$ & $x$ \\
\hline
\end{tabular}


İzmirli kadın girişimcilerin Facebook'taki işletmelerine ait profil sayfaları incelemesine göre profil sayfalarında kurum logosu ve kurumsal kapak fotoğrafları işletmeler tarafından ağırlıklı olarak tercih edildiği görülmektedir. İncelenen 8 işletmenin 7 'sinde kurum logosu, 5'inde kurumsal kapak fotoğrafı saptanmıştır. Araştırma kapsamında düzenli durum güncellemeleri incelenmiş, sadece 5 işletmenin düzenli durum güncellemesi yaparak Facebook sayfalarını güncel tuttukları saptanmıştır. Tüketicilerin zihninde markayla ilgili yaratılmaya çalışılan değerler zinciri ve iletişim çalışmaların rolü değerlendirildiğinde kullanıcılara markayı anlatan yeni ve güncel bilgiler sunulması önem taşımaktadır. İzmirli kadın girişimcilerin Facebook'taki işletmelerine ait profil sayfaları incelendiğinde tüm markaların sayfalarında içerik ürettikleri saptanmıştır. Bu bağlamda tüketicileriyle iletişim kurma alanı olarak tercih ettikleri bu aracı, içerik üreterek doğru kullandıkları belirtilebilmektedir. Ancak analiz edilen tüm işletmelerin sayfaları içerik üretirken, hiçbir işletmenin kullanıcılardan gelen yorumlara cevap vermemeleri önemli bir veridir. İşletmelerin özellikle kurumsal adlarıla tüketicilere cevap vererek markayla tüketici arasında güven olgusunu yaratması önem taşımaktadır. Kurumsal bir perspektif çerçevesinde markaların hızlı ve doğru bir şekilde üretilen içeriklere gelen yorumlara cevap vererek tüketici ile interaktif bir iletişim kurması daha doğrudur. Değerlendirilen işletmelerin Facebook sayfaları verilerine göre sadece bir işletme dışında diğer işletmelerin Facebook sayfalarında içerikleriyle ilgili linklerle kullanıcıları yönlendirdikleri saptanmıştır. Ayrıca ilgili sayfalar açısından dikkat çekici bir durum olarak 7 işletmede, işletmenin ismiyle aynı isimli başka Facebook sayfalarına rastlanmıştır. Bu durum ilgili markanın sayfasını arayan potansiyel hedef kitle için bir tehdit oluşturabilmektedir. Beğeni ve takipçi sayıları irdelendiğinde herhangi bir standart dağılım göze çarpmamakta ve işletmelere göre farklılıklar olduğu belirtilebilmektedir. Profil sayfaları çerçevesinde tespit edilen bir diğer konu da F-Ticaret yaparak kullanıcıları aynı zamanda sayfa aracılığıyla satın alma davranışına yönlendirip yönlendirmediğidir. Bu bağlamda 2 işletmenin sayfasında F-Ticaret uyguladığı saptanmıştır. 
RQ: İzmirli kadın girişimciler, tüketicilerine yönelik hangi ekme stratejisini çevrimiçi iletişim kurmak için kullanmaktadırlar?

Tablo 2: Kurumsal Sayfa Geliştirmede Ekme Stratejisi: Açıklık

\begin{tabular}{|c|c|c|c|c|c|c|c|c|}
\hline Açılklık & $\begin{array}{l}\text { Zeytin } \\
\text { Kostü } \\
\text { mü }\end{array}$ & $\begin{array}{l}\text { Süslü } \\
\text { Kasa } \\
\text { p }\end{array}$ & $\begin{array}{l}\text { Kidolind } \\
\text { o }\end{array}$ & $\begin{array}{l}\text { İdivi } \\
\text { no }\end{array}$ & $\begin{array}{l}\text { Tortier } \\
\text { a }\end{array}$ & $\begin{array}{l}\text { Shape } \\
\text { s } \\
\text { Merk } \\
\text { ez }\end{array}$ & $\begin{array}{l}\text { Kurabi } \\
\text { ye } \\
\text { Canava } \\
\text { n1 }\end{array}$ & $\begin{array}{l}\text { Bia } \\
\text { H.i. } \\
\text { R }\end{array}$ \\
\hline Açıklama / Tarihçe & $X$ & $\sqrt{ }$ & $\sqrt{ }$ & $\sqrt{ }$ & $\sqrt{ }$ & $\sqrt{ }$ & $\sqrt{ }$ & $\sqrt{ }$ \\
\hline Misyon & $X$ & $X$ & $X$ & $\sqrt{ }$ & $X$ & $\sqrt{ }$ & $\bar{x}$ & $x$ \\
\hline Vizyon & $X$ & $X$ & $X$ & $\sqrt{ }$ & $X$ & $\sqrt{ }$ & $x$ & $\mathrm{X}$ \\
\hline Amaç & $X$ & $\sqrt{ }$ & $x$ & $\sqrt{ }$ & 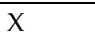 & $\sqrt{ }$ & $\bar{x}$ & $X$ \\
\hline Kurucu Bilgileri & $x$ & $x$ & $x$ & $x$ & $x$ & $x$ & $x$ & $x$ \\
\hline $\begin{array}{ll}\text { Girişimci } & \text { adına } \\
\text { hiperlink } & \\
\end{array}$ & $\bar{X}$ & $X$ & $x$ & $X$ & $x$ & $x$ & $x$ & $\mathrm{X}$ \\
\hline $\begin{array}{lc}\text { Kurumsal } & \text { Siteye } \\
\text { Hiperlink } & \\
\end{array}$ & $\sqrt{ }$ & $\sqrt{ }$ & $\sqrt{ }$ & $\sqrt{ }$ & $\sqrt{ }$ & $\sqrt{ }$ & $X$ & $\sqrt{ }$ \\
\hline $\begin{array}{l}\text { Başka logo ve } \\
\text { görsel kullanımı }\end{array}$ & $x$ & $\sqrt{ }$ & $X$ & $X$ & $X$ & $x$ & $x$ & $x$ \\
\hline
\end{tabular}

Yapılan araştırma kapsamında 1 işletme dışında kalan 7 işletme Facebook sayfasında markalarıyla ilgili genel bir açıklama veya tarihçeleriyle ilgili bilgi vermektedir. Sadece 2 işletme misyon ve vizyonlarını kullanıcılara aktarmaktadır. Bu verilerde dikkat çekici olan nokta misyonlarını belirten işletmelerin aynı zamanda vizyonlarına da yer vermiş olmalarıdır. Bir diğer ifadeyle işletmeler, misyon ve vizyonlarına bir arada yer vermiş veya hiç yer vermemişlerdir. İşletmeler arasında sadece 3 işletme amaçlarına yer vermiştir ve bu işletmelerin 2 tanesi aynı zamanda misyon ve vizyonunu belirten işletmelerdir. Ayn zamanda bir diğer dikkat çekici veri de hiçbir işletmenin kurucu bilgilerine yer vermemiş olmasıdır. $\mathrm{Bu}$ bağlamda işletmelerin ortaklık yapısı, kurucu isimleri gibi bilgilerin tüketicilerle paylaşılmaması tüketicilerle oluşturulması hedeflenen güven olgusunun oluşumunda eksiklik yaratabilmektedir. Aynı çerçevede girişimci adına hiperlinke de rastlanmamıştır. Ancak 7 işletme kurumsal sitelerine hiperlink vermiş, bu durumda tüketiciyi kurumsal web sitesine yönlendirme ve iletişim çalışmalarına diğer bir kanal ile devam etme açısından önem taşımaktadır. Sadece 1 işletme dışındaki diğer tüm işletmelerin sayfasında kurumsal logo dişında herhangi bir logo ve görsel kullanımına rastlanılmamıştır. 
Tablo 3: Kurumsal Sayfa Geliştirmede Ekme Stratejisi: Bilgiyi Yayma

\begin{tabular}{|c|c|c|c|c|c|c|c|c|}
\hline Bilgiyi yayma & $\begin{array}{l}\text { Zeytin } \\
\text { Kostümü }\end{array}$ & $\begin{array}{l}\text { Süslü } \\
\text { Kasap }\end{array}$ & $\begin{array}{l}\text { Kidoli } \\
\text { ndo }\end{array}$ & İdivino & $\begin{array}{l}\text { Tortier } \\
\text { a }\end{array}$ & $\begin{array}{l}\text { Shapes } \\
\text { Merkez }\end{array}$ & $\begin{array}{l}\text { Kurabiye } \\
\text { Canavarı }\end{array}$ & $\begin{array}{l}\text { Bia } \\
\text { H.I.I.R. }\end{array}$ \\
\hline Video yükleme & $x$ & $\mathrm{x}$ & $\sqrt{ }$ & $\sqrt{ }$ & $\mathrm{x}$ & $\sqrt{ }$ & $\mathrm{x}$ & $\mathrm{X}$ \\
\hline Fotoğraf yükleme & $\sqrt{ }$ & $\sqrt{ }$ & $\sqrt{ }$ & $x$ & $\sqrt{ }$ & $\sqrt{ }$ & $\sqrt{ }$ & $\sqrt{ }$ \\
\hline $\begin{array}{l}\text { Hizmetle, } \\
\text { sorunla ilgili } \\
\text { kamuyu } \\
\text { bilgilendirme }\end{array}$ & $x$ & $\sqrt{ }$ & $\sqrt{ }$ & $x$ & $\sqrt{ }$ & $\sqrt{ }$ & $x$ & $\sqrt{ }$ \\
\hline $\begin{array}{l}\text { Ürünlerle ilgili } \\
\text { bilgi }\end{array}$ & $\sqrt{ }$ & $\sqrt{ }$ & $x$ & $\mathrm{X}$ & $\sqrt{ }$ & $\mathrm{x}$ & $x$ & $\mathrm{x}$ \\
\hline $\begin{array}{l}\text { Tutundurma } \\
\text { bilgisi }\end{array}$ & $x$ & $\sqrt{ }$ & $\sqrt{ }$ & $x$ & $\sqrt{ }$ & $x$ & $x$ & $x$ \\
\hline Şirket bilgisi & $\mathrm{x}$ & $\mathrm{x}$ & $\mathrm{x}$ & $\sqrt{ }$ & $\mathrm{x}$ & $\sqrt{ }$ & $\mathrm{x}$ & $\sqrt{ }$ \\
\hline $\begin{array}{l}\text { Medya } \\
\text { linkleri }\end{array}$ & $x$ & $x$ & $\sqrt{ }$ & $x$ & $\sqrt{ }$ & $\sqrt{ }$ & $x$ & $x$ \\
\hline İnfografik/Grafik & $x$ & $x$ & $x$ & $\sqrt{ }$ & $x$ & $x$ & $x$ & $x$ \\
\hline $\begin{array}{ll}\text { Mikro } & \text { site } \\
\text { linkleri } & \end{array}$ & $\sqrt{ }$ & $\sqrt{ }$ & $\sqrt{ }$ & $x$ & $\sqrt{ }$ & $\sqrt{ }$ & $x$ & $x$ \\
\hline
\end{tabular}

Yapılan araştırma verileri incelendiğinde; İzmirli kadın girişimcilerin Facebook sayfalarında fotoğraf yüklemenin 7 işletme tarafından, video yüklemenin ise sadece 3 işletme tarafından tercih edildiği saptanmıştır. 5 işletme, işletmesine ait bir hizmet veya işletmeden kaynaklanan bir sorunla ilgili kamuyu bilgilendirmektedir. Özellikle kamunun bu tür konularda bilgilendirilmesi tüketiciyle doğrudan iletişim kurabilme ve tüketicinin zihninde markayla ilgili oluşabilecek olumsuzlukları yaratmama açısından önem taşımaktadır. Facebook sayfası aracılığıyla sadece 3 işletme tutundurma çalışması gerçekleştirmektedir. Özellikle tüketicilerle sık ve düşük maliyetlerde iletişim kurulabilen bir alan olan Facebook'un işletmelerin reklam, halkla ilişkiler vb tutundurma faaliyetlerinde etkin kullanımı marka iletişimi açısından önem taşımaktadır. İşletmelere ait kuruluş yılı, şirket yapısı vb şirket detaylarının yer aldığ şirket bilgisi incelendiğinde sadece 3 işletmenin bu bilgilere yer verdiği saptanmıştır. İ̧̧letmelere ait haberlerin linkleri sayfalarda incelendiğinde ise sadece 3 işletmenin bu linklere yer verdiği görülmektedir. İnfografik/Grafik türü görseller taranmış ve 1 işletmenin sayfasında bu görsellere yer verdiği saptanmıştır. Ancak genellikle işletmelerin mikro site linklerini Facebook sayfalarında paylaşarak diğer mikro sitelere yönlendirme yaptıkları değerlendirilmiştir. Özellikle diğer sitelere yönlendirme yapılarak diğer araçlarda da işletmeyle ilgili bilgilere erişim sağlanması iletişim süreci açısından önem taşımaktadır. 
Tablo 4: Kurumsal Sayfa Geliştirmede Ekme Stratejisi: İnteraktiflik ve İlginlik

\begin{tabular}{|l|l|l|l|l|l|l|l|l|}
\hline $\begin{array}{l}\text { İnteraktiflik } \\
\text { ve ilginlik }\end{array}$ & $\begin{array}{l}\text { Zeytin } \\
\text { Kostümü }\end{array}$ & $\begin{array}{l}\text { Süslü } \\
\text { Kasap }\end{array}$ & $\begin{array}{l}\text { Kidolin } \\
\text { do }\end{array}$ & $\begin{array}{l}\text { İdivin } \\
\mathbf{o}\end{array}$ & $\begin{array}{l}\text { Tortier } \\
\mathbf{a}\end{array}$ & $\begin{array}{l}\text { Shapes } \\
\text { Merkez }\end{array}$ & $\begin{array}{l}\text { Kurabiy } \\
\text { e } \\
\text { Canavarı }\end{array}$ & $\begin{array}{l}\text { Bia } \\
\text { H.I. } \\
\text { R. }\end{array}$ \\
\hline $\begin{array}{l}\text { Kurumsal } \\
\text { iletişim } \\
\text { bilgileri }\end{array}$ & $\mathrm{X}$ & $\sqrt{ }$ & $\mathrm{X}$ & $\sqrt{ }$ & $\sqrt{ }$ & $\sqrt{ }$ & $\mathrm{X}$ & $\sqrt{ }$ \\
\hline $\begin{array}{l}\text { Şirkete mesaj } \\
\text { gönderme }\end{array}$ & $\sqrt{ }$ & $\sqrt{ }$ & $\sqrt{ }$ & $\sqrt{ }$ & $\sqrt{ }$ & $\sqrt{ }$ & $\mathrm{X}$ & $\sqrt{ }$ \\
\hline $\begin{array}{l}\text { Bir arkadaşa } \\
\text { Önerme/davet }\end{array}$ & $\mathrm{X}$ & $\sqrt{ }$ & $\sqrt{ }$ & $\sqrt{ }$ & $\sqrt{ }$ & $\sqrt{ }$ & $\mathrm{X}$ & $\sqrt{ }$ \\
\hline $\begin{array}{l}\text { Soru cevap } \\
\text { bölümü }\end{array}$ & $\mathrm{X}$ & $\mathrm{X}$ & $\mathrm{X}$ & $\mathrm{X}$ & $\mathrm{X}$ & $\mathrm{X}$ & $\mathrm{X}$ & $\mathrm{X}$ \\
\hline $\begin{array}{l}\text { Değerlendirme, } \\
\text { küçük anket }\end{array}$ & $\mathrm{X}$ & $\sqrt{ }$ & $\mathrm{X}$ & $\mathrm{X}$ & $\sqrt{ }$ & $\mathrm{X}$ & $\mathrm{X}$ & $\sqrt{ }$ \\
\hline $\begin{array}{l}\text { Uygulama } \\
\text { (Aplikasyon) }\end{array}$ & $\mathrm{X}$ & $\mathrm{X}$ & $\mathrm{X}$ & $\sqrt{ }$ & $\mathrm{X}$ & $\mathrm{X}$ & $\mathrm{X}$ & $\mathrm{X}$ \\
\hline
\end{tabular}

İlgili işletmelerin Facebook sayfalarında telefon, faks, e-mail ve adres bilgilerini kapsayan kurumsal iletişim bilgileri incelenmiş ve 5 işletmenin bu bilgileri erişime verdiği, 3 işletmenin ise bu bilgileri kullanıcılarla paylaşmadığı saptanmıştır. 1 işletme dışında tüm işletmelerin kullanıcıları işletmeye mesaj gönderebilmekte, 6 işletmenin kullanıcısı ise bir arkadaşı önerip veya sayfaya davet edebilmektedir. Ayrıca hiçbir işletme Facebook sayfasında soru cevap bölümünü kullanmamaktadır. Diğer yandan sadece 2 işletme değerlendirme ve küçük anketi kullanmaktadır. Ayrıca sadece 1 işletme uygulamaya yer vermiştir. Bu bağlamda genel olarak veriler değerlendirildiğinde incelenen sayfalar genelinde işletmelerin Facebook sayfalarındaki tüketicileriyle interaktif iletişim kullanabilecekleri araçları etkin bir şekilde kullanmadıkları belirtilebilmektedir.

Tablo 2, Tablo 3 ve Tablo 4 değerlendirildiğinde işletmelerin ekme stratejisinin etkin olarak kullanmadıkları belirtilebilmektedir. İşletmelerin bu stratejiyi etkin olarak kullanmaları iletişim çalışmalarının daha başarılı olmasına ve tüketicilerin zihninde oluşturmak istedikleri marka imajının güçlenmesini destekleyeceği söylenebilmektedir. 
RQ: İzmirli Kadın girişimciler ne tür içerik türlerini seçmekte ve kullanmaktadırlar.

Tablo 5: Kadın girişimcilerin Facebook sayfalarındaki içerik formatları

\begin{tabular}{|l|l|l|l|l|l|l|l|l|}
\hline & $\begin{array}{l}\text { Zeytin } \\
\text { Kostü } \\
\mathbf{m}\end{array}$ & $\begin{array}{l}\text { Süsl } \\
\text { ü } \\
\text { Kasa } \\
\mathbf{p}\end{array}$ & $\begin{array}{l}\text { Kidol } \\
\text { ino }\end{array}$ & $\begin{array}{l}\text { Ídivi } \\
\text { no }\end{array}$ & $\begin{array}{l}\text { Tortier } \\
\mathbf{a}\end{array}$ & $\begin{array}{l}\text { Shapes } \\
\text { Merke } \\
\mathbf{z}\end{array}$ & $\begin{array}{l}\text { Kurabiye } \\
\text { Canavarı }\end{array}$ & $\begin{array}{l}\text { Bia } \\
\text { H.I..R. }\end{array}$ \\
\hline Metin & $\sqrt{ }$ & $\sqrt{ }$ & $\sqrt{ }$ & $\sqrt{ }$ & $\sqrt{ }$ & $\sqrt{ }$ & X & $\sqrt{ }$ \\
\hline Hiperteks & $\mathrm{X}$ & $\sqrt{ }$ & $\mathrm{X}$ & $\sqrt{ }$ & $\sqrt{ }$ & $\sqrt{ }$ & $\mathrm{X}$ & $\sqrt{ }$ \\
\hline Video & $\mathrm{X}$ & $\mathrm{X}$ & $\sqrt{ }$ & $\mathrm{X}$ & $\mathrm{X}$ & $\sqrt{ }$ & $\mathrm{X}$ & $\mathrm{X}$ \\
\hline Fotoğraf & $\sqrt{ }$ & $\sqrt{ }$ & $\sqrt{ }$ & $\sqrt{ }$ & $\sqrt{ }$ & $\sqrt{ }$ & $\sqrt{ }$ & $\sqrt{ }$ \\
\hline $\begin{array}{l}\text { İnfografik/Grafi } \\
\text { k/ } \\
\text { İllüstrasyon }\end{array}$ & $\mathrm{X}$ & $\mathrm{X}$ & $\sqrt{ }$ & $\sqrt{ }$ & $\mathrm{X}$ & $\mathrm{X}$ & $\mathrm{X}$ & $\mathrm{X}$ \\
\hline
\end{tabular}

Tablo 5 incelendiğinde İzmirli kadın girişimcilerin hepsinin Facebook sayfalarına fotoğraf yükledikleri görülmektedir. 7 girişimci Facebook sayfasında metin kullanmakta ve kullanıcılarıyla video, fotoğraf, grafik vb. görsel destek kullanmanın yanı sıra aynı zamanda üretilen içerikte metin temelli veya metin destekli olarak tercih etmektedir. 5 girişimci hiperteksler ekleyerek kullanıcıları başka görsel, metin vb. bulunduğu linklere yönlendirirken 3 girişimci bu içerik oluşumunu tercih etmemektedir. Veriler incelendiğinde video içerik yüklemesinin fotoğraf gibi yoğun olarak tercih edilmediği sadece 2 girişimcinin sayfasında video saptandığ1 belirtilebilmektedir. Aynı şekilde infografik, grafik ve illüstrasyon kullanan girişimci sadece 2 tanedir. Araştırma verilerine göre tüm içerik üretim formatlarını kullanan girişimciye rastlanmamıştır. 


\section{RQ: Kadın girişimciler tüketicilerle nasıl diyalog kuruyorlar?}

Tablo 6: İzmirli Kadın girişimcilerin kurumsal Facebook sayfası içerik konuları

\begin{tabular}{|c|c|c|c|c|c|c|c|c|}
\hline & $\begin{array}{l}\text { Zeytin } \\
\text { Kostüm }\end{array}$ & $\begin{array}{l}\text { Süslü } \\
\text { Kasap }\end{array}$ & Kidolino & İdivino & Tortiera & $\begin{array}{l}\text { Shapes } \\
\text { Merkez }\end{array}$ & $\begin{array}{l}\text { Kurabiye } \\
\text { Canavarı }\end{array}$ & $\begin{array}{l}\text { Bia } \\
\text { H.I.t.R. }\end{array}$ \\
\hline $\begin{array}{l}\text { Ürün / } \\
\text { hizmetle } \\
\text { ilgili içerik } \\
\left(\mathrm{E} / \mathrm{B}^{*}\right)\end{array}$ & E & B & $\mathrm{E} / \mathrm{B}$ & B & E & B & B & B \\
\hline $\begin{array}{l}\text { Reklam } \\
\text { içerikleri }\end{array}$ & $x$ & $X$ & $\sqrt{ }$ & $x$ & $\sqrt{ }$ & $\sqrt{ }$ & $x$ & $X$ \\
\hline $\begin{array}{l}\text { Halkla } \\
\text { İlişkiler } \\
\text { içerikleri }\end{array}$ & $X$ & $\bar{X}$ & $\sqrt{ }$ & $X$ & $X$ & $X$ & $\bar{X}$ & $\sqrt{ }$ \\
\hline $\begin{array}{l}\text { Doğrudan } \\
\text { pazarlama } \\
\text { içerikleri }\end{array}$ & $X$ & $\sqrt{ }$ & $\sqrt{ }$ & $X$ & $x$ & $X$ & $X$ & $X$ \\
\hline $\begin{array}{l}\text { Kişisel satış } \\
\text { içerikleri }\end{array}$ & $X$ & $X$ & $\sqrt{ }$ & $X$ & $x$ & $X$ & $X$ & $X$ \\
\hline $\begin{array}{l}\text { Şirketle ilgili } \\
\text { içerikler }\end{array}$ & $X$ & $\bar{X}$ & $X$ & $X$ & $X$ & $X$ & $\bar{X}$ & $X$ \\
\hline $\begin{array}{l}\text { Kullanıcıdan } \\
\text { gelen } \\
\text { yorumlara } \\
\text { yönelik } \\
\text { içerikler }\end{array}$ & $X$ & $X$ & $x$ & $X$ & $x$ & $X$ & $X$ & $X$ \\
\hline $\begin{array}{l}\text { Marka dış1 } \\
\text { ilgisiz içerik }\end{array}$ & $x$ & $x$ & $x$ & $\sqrt{ }$ & $x$ & $\sqrt{ }$ & $x$ & $\sqrt{ }$ \\
\hline
\end{tabular}

\section{${ }^{*} \mathrm{E}$ : Eğlendirici içerik B: Bilgilendirici içerik}

İçerik analiz kapsamında; kadın girişimcilerin kurumsal Facebook sayfalarında yer alan ürün / hizmetle ilgili bilgilerin, eğlendirici tarzda mı yoksa bilgilendirici tarzda $\mathrm{ml}$ üretildiği incelenmiştir. $\mathrm{Bu}$ çerçevede 5 girişimcinin içeriklerini bilgilendirici tarzda ürettikleri, 2 girişimcinin eğlendirici tarzda, 1 girişimcinin ise hem bilgilendirici hem de eğlendirici tarzda içerik ürettiği saptanmıştır. Bu bağlamda işletmelerin bilgi ve eğlenceyi bir arada kullanmaktan çok bir tarz seçerek tüketiciyle iletişim kurdukları mesaj tonlarında tek tarza yöneldikleri dikkat çekmektedir. Ayrıca Facebook sayfasında üretilen içeriklerdeki reklam mesajları incelendiğinde sadece 3 girişimcinin sayfasında reklam içeriklerine rastlanmıştır. Bir diğer yandan sadece 2 girişimcinin sayfasında halkla ilişkiler ve doğrudan pazarlama içerikleri yer almaktadır. Kişisel satış içeriklerine ise sadece 1 girişimcinin sayfasında yer verilmiştir. Reklam, halkla ilişkiler, doğrudan pazarlama ve kişisel satış içerikleri değerlendirildiğinde hepsini kullanan sadece tek bir işletmenin olması diğer 
işletmelerin ya hiç ya da sadece birini kullandığı görülmüştür. Hedef kitleye ulaşmada düşük maliyetli ve etkili bir mecra olan Facebook'un analiz kapsamında incelenen girişimler tarafından çok yoğun olarak kullanılmadığı dikkat çekmiştir. Bir diğer yandan hiçbir işletmenin şirketin üretim tesisleri, lojistik, satış sonrası servis vb konularda işletmeyle ilgili içerik üretmemesi ve kullanıcıdan gelen yorumlara yönelik içerik üretmemesi bir diğer ifadeyle kullanıcı yorumlarına cevap vermemesi dikkat çekmiştir. Ayrıca İzmirli kadın girişimcilerin Facebook sayfasında marka dışı ilgisiz içerik üreten 3 işletmeye rastlanmıştır. Bu işletmeler markalarından bağımsız olarak bir başka markayla ilgili olarak tüketicilere bilgi vermektedir. Genel olarak Tablo 6 değerlendirildiğinde girişimcilerin Facebook sayfalarında içerik konularında iletişim çalışmalarına yeterince yer vermediği ve tüm iletişim kanallarını kullanmadığı görülmektedir.

\section{RQ: Kadın girişimcilerin en çok öne çıkan içerikleri}

Tablo 7: İzmirli kadın girişimcilerin Facebook sayfalarındaki en popüler içerikler

\begin{tabular}{|c|c|c|c|c|c|c|c|c|}
\hline & $\begin{array}{l}\text { Zeytin } \\
\text { Kostü } \\
\text { m }\end{array}$ & $\begin{array}{l}\text { Süslü } \\
\text { Kasap }\end{array}$ & $\begin{array}{l}\text { Kidolind } \\
\text { o }\end{array}$ & $\begin{array}{l}\text { İdivin } \\
\text { o }\end{array}$ & Tortiera & $\begin{array}{l}\text { Shapes } \\
\text { Merkez }\end{array}$ & $\begin{array}{l}\text { Kurabiy } \\
\text { e } \\
\text { Canavar } \\
1\end{array}$ & $\begin{array}{l}\text { Bia } \\
\text { H.İ.R. }\end{array}$ \\
\hline $\begin{array}{l}\text { En çok } \\
\text { beğenile } \\
n \text { post } \\
\text { içeriği }\end{array}$ & $\begin{array}{l}\text { Etkinli } \\
\mathrm{k}\end{array}$ & $\begin{array}{l}\text { Çocukları } \\
\mathrm{n} \\
\text { beslenme } \\
\text { si }\end{array}$ & $\begin{array}{l}\text { Çocukları } \\
\mathrm{n} \\
\text { beslenme } \\
\text { si }\end{array}$ & $\begin{array}{l}\text { Özlü } \\
\text { söz }\end{array}$ & $\begin{array}{l}\text { Babyshow } \\
\text { er pastası }\end{array}$ & $\begin{array}{l}\text { Franchisin } \\
\mathrm{g}\end{array}$ & $\begin{array}{l}\text { Ürün } \\
\text { görseli }\end{array}$ & $\begin{array}{l}\text { Bayra } \\
\mathrm{m} \\
\text { tebriği }\end{array}$ \\
\hline Beğenme & 9 & 187 & 124 & 4 & 36 & 28 & 21 & 13 \\
\hline Yorum & 0 & 1 & 17 & 0 & 0 & 0 & 0 & 0 \\
\hline Paylaşım & 0 & 1 & 2 & 0 & 0 & 1 & 0 & 0 \\
\hline $\begin{array}{l}\text { En çok } \\
\text { paylaşıla } \\
\text { n post } \\
\text { içeriği }\end{array}$ & $x$ & $\begin{array}{l}\text { Yemek } \\
\text { tarifi }\end{array}$ & $\begin{array}{l}\text { Aktivite } \\
\text { önerisi }\end{array}$ & $\begin{array}{l}\text { Özlü } \\
\text { söz }\end{array}$ & $\begin{array}{l}\text { Özel gün } \\
\text { etkinlik }\end{array}$ & $\begin{array}{l}\text { Satış } \\
\text { promosyon } \\
\text { u /Ücretsiz } \\
\text { ödül ürünü }\end{array}$ & $\begin{array}{l}\text { Ürün } \\
\text { görseli }\end{array}$ & $\begin{array}{l}\text { Ürün } \\
\text { tanitı } \\
\text { mı }\end{array}$ \\
\hline Paylaşım & $X$ & 25 & 34 & 4 & 12 & 46 & 27 & 14 \\
\hline
\end{tabular}

Tablo 7'de her bir girişimcinin Facebook sayfalarındaki en fazla beğeni ve paylaşım alan içerikleri incelenmiştir. En çok beğenilen ve en çok paylaşılan içerikler çerçevesinde analiz edilen girişimci sayfaları arasında ilk ve ikinci sırada yer alan beğeniyi, çocukların beslenmesiyle ilgili üretilen içerik alırken; en yüksek paylaşım sayısını ücretsiz ödül ürününün bilgisini veren satış promosyon içeriği almıştır. İkinci sırada ise çocukların beslenmesi ile ilgili üretilen içerik paylaşım almaktadır. En az beğeniye ve paylaşıma ait içeriğin konusu özlü sözdür. Bu bağlamda sayfa kullanıcıların 
marka veya marka dişı konularda genellikle bilgi veren içerikleri beğendikleri belirtilebilmektedir.

\section{Değerlendirme ve Sonuç}

Markalaşma sürecinin önemli bir parçası olan tüketicilerle bağ kurma ve markaya ait mesajların iletimi sürecinde girişimlerin sosyal medyayı kullanmaları her geçen gün daha da önemli bir hale gelmektedir. Kadın girişimcilerin markalaşma sürecinde sosyal medya kullanımları değerlendirildiğinde bu aracı yeterli düzeyde kullanmadıkları saptanmıştır. Özellikle tutundurma çalışmalarında sosyal medyayı etkin kullanmadıkları belirlenmiştir.

İçerik üretim formatlarında fotoğraf ve metin ağırlıklı üretimlere önem verildiği hedef kitlenin dikkatini çekecek diğer formatların çok fazla tercih edilmediği görülmüştür.

Ancak işletmelerin özellikle ürün ve hizmetlerine yönelik bilgiyi paylaşma sürecinde başarılı oldukları belirlenmiş, bu durum da markalaşma süreci için olumlu adımlar olarak değerlendirilebilmektedir.

Facebook'ta incelenen kadın girişimcilere ait sayfalardan yola çıkılarak, öncelikle kuruma ait kurumsal bilgilerin eksiksiz ve güncel olmasının tüketicinin bilgi erişimi için önemi büyüktür. $\mathrm{Bu}$ nedenle, sayfaların özellikle marka iletişimi açısından güncelliğinin sık sık kontrol edilmesi esastır.

Kurumsal kimlik ögeleri de eksiksiz olarak yer alabilmelidir. Kurumsal itibar yönetiminde kurum kimliğinin en önemli ögelerinden biri kurum logosu, sloganı ve renkleridir. Özellikle kurum hakkında arama motorlarında görsel aramalar yapılırken, kuruma ait resmi Facebook hesaplarında yer alan görseller, optimizasyonda üst sıralarda yer almasını sağlamakla beraber, kurumsal itibara da katkı sağlayacaktır. Dolayısıyla kurumsal görsel seçimine de dikkat edilmelidir.

Facebook üzerinden marka iletişiminde en önemli unsurlar arasında genellikle takipçi sayısını yükseltmek büyük bir başarı olarak düşünülmektedir. Ancak takipçi sayısı kadar, takipçilerle aktif iletişim kurmak da oldukça önemlidir. Tüketici eğer kurumsal bir sayfayı takip ediyor, gelen paylaşımlarla ilgilenip marka ile iletişimi sürdürüyorsa, takipçilik aktif bir hale gelmektedir. Aktiflikten bir diğer kasıt da, marka adına içerik üreticisinin tüketiciden gelen yorumlara hızlı ve yapıcı cevap vermesidir. Özellikle tüketicilerin marka ile iletişime geçmesinde yoğun olarak kullandıkları Facebook'a ait "Beğen, paylaş ve yorum yap" seçenekleri, markaların da yoğun ve aktif bir şekilde kullandıkları bir uygulama olmalıdır. Sadece tüketiciler değil, markalar da tüketicilerin 
yazdıkları içerikleri beğenmeli, yorum yapmalı ve paylaşmalıdır. Bu etkileşim marka ile tüketici arasındaki iletişimi güçlendirmektedir.

Facebook'taki kurumsal sayfalarında koymuş olduğu kurumsal içeriklere yapılan yorumlar, tüketicilerin de birbirleriyle aktif olarak etkileşime girdiği ortamlardır. Bu tür ortamlar geliştikçe, markalar sadece tüketicilerin yorumlarını dinlemekle kalmayıp kendilerini beğenen toplulukların birbirleriyle iletişime geçmelerine de katkıda bulunmaktadirlar.

İşletmelerin kurumsal Facebook sayfalarında markalarının tutundurma çalışmalarıyla ilgili güncel bilgilere yer vermesi, ürün/hizmetle ilgili güncel içeriklerin oluşturulması markanın tüketici algısı için önemlidir. Reklam, halkla ilişkiler, doğrudan pazarlama ve kişisel satış içerikleri ile tüketicilerin kampanyalarla ilgili bilgilendirilmesi tüketicilerin markayı takip etme motivasyonunu arttıran unsurlardan biridir. Bu nedenle kurumsal sayfalarda marka iletişimi kapsamında verilen stratejik kararların uygulanmasına yönelik güncel bilgilere yer verilmelidir.

Gerek tüketiciler gerekse markalar ve girişimciler için her geçen gün kullanım oranı artan sosyal medya, araştırmacılar için de önemli verilere ışık tutmaya devam etmektedir. Her geçen gün sosyal medyaya farklı bir disiplinden, farklı bir alt başlıktan bakarak yaklaşan araştırmalar, sosyal medyanın zenginliğinden yararlanmaktadır. Aynen bu çalışmada da olduğu gibi araştırmacılar, mevcut bir kadın araştırmasının ışığından yola çıkarak, sosyal medya araştırmalarını ileriye götüreceklerdir. Örneğin Facebook kadın kullanıcıları, Facebook'taki kadın girişimciler, Facebook'ta kadınlara yönelik markalar, Facebook'ta faaliyet gösteren kadın politikacılar, kadın liderler gibi farklı açılarla geliştirilen araştırmalar, özel sektöre de önemli veriler sunacaktır. Bu çalışma için de gelecekte sadece İzmir'i değil, tüm Türkiye genelini kapsayacak bir şekilde araştırma genişletilebilir ve konuyla ilgili farklı değerlendirmeler yapılabilir. Ayrıca bu çalışmanın bir sonraki aşamasında, Facebook sayfaları incelenen kadın girişimcilerle, derinlemesine görüşme yapılarak sosyal medya üzerinden marka iletişimi konusundaki tutumları ve çabalarına yönelik düşünceleri de değerlendirilebilir.

\section{Kaynakça}

ALGÜR, S. \& Cengiz, F. (2011). Türk Tüketicilere Göre Online (Çevrimiçi) Alışverişin Riskleri ve Yararları. Journal of Yaşar University, Vol. 22 (6), ss. 3666-3680. 
AVERY, E., Lariscy, R., Amador, E., Ickowitz, T., Primm, C. \& Taylor, A. (2010). Diffusion of social media among public relations practitioners in health departments across various community population sizes. Journal of Public Relations Research, 22(3), 336358.

CANARY, D. J., \& Stafford, L. (1992). Relational maintenance strategies and equity in marriage. Communication Monographs, 59(3), 243-67.

ÇELEBİ, N. (1990). Kadınlarımızın Cinsiyet Rolü Tutumları, Konya: Sebat Matbaasi.

EMSEN, Ö. (2001). “Genç Nesilde Mesleki Eğilimler ve Girişimcilik : Ampirik Bir Çalışma", MPM Verimlilik Dergisi, Sayı 2001/1, 153-176.

ERTÜBEY, N. Ö. (1993). “Türkiye'de Kadın Girişimciliği: Mevcut Durum, Sorunlar ve Öneriler" Türkiye'de Kadın Girişimcilik, Necla Arat (der.), ss.244-255.

GALLOWAY, S. (2012). L2 Facebook IQ index. New York: NYU Stern.

GINOSSAR, T. (2008). Online participation: A content analysis of differences in utilization of two online cancer communities by men and women, patients and family members. Health Communication, 23, ss. 1-12.

GRUNIG, J. E. \& Huang, Y. H. (2000). From organizational effectiveness to relationship indicators: Antecedents of relationships, public relations strategies, and relationship outcomes.

LEDINGHAM, J. A. \& S. D. Bruning (Eds.), Public relations as relationship management: A relational approach to the study and practice of public relations (ss. 23-54). Mahwah, NJ: Erlbaum.

HISRICH, R. D. \& Öztürk, S. A. (1999). "Women Entrepreneurs in a Developing Economy", The Journal of Management Development, Cilt18 Sayı 2, ss.114-125.

HISRICH, R. D. \& Peters, M. P. (1989). Starting, Developing and Managing a New Enterprise, Homewood, IL:BPI.

HUNG, C. J. F. (2006). Toward the theory of relationship management in public relations: How to cultivate quality relationships? In E. L. Toth (Ed.), The future of excellence in public relations and communication management (pp. 443-476). Mahwah, NJ: Erlbaum.

KARA, Y. \& Coşkun, A. (2012). Sosyal Ağların Pazarlama Aracı Olarak Kullanımı: Türkiye'deki Hazır Giyim Firmaları Örneği. Afyon Kocatepe Üniversitesi, İ̈BF Dergisi, Cilt 14 (2), ss.73-90.

KELLEHER, T. \& Miller, B. M. (2006). Organizational blogs and the human voice: Relational strategies and relational outcomes. Journal of Computer-Mediated Communication, 99, 395-414. 
KENT, M. L. \& Taylor, M. (1998). Building dialogic relationships through the World Wide Web. Public Relations Review, 24(3), 321-334.

KENT, M. L. \& Taylor, M. (2002). Toward a dialogic theory of public relations. Public Relations Review, 28, 21-37.

KENT, M. L. (2008). Critical analysis of blogging in public relations. Public Relations Review, 4(1), 32-40.

KI, E. J. \& Hon, L. C. (2006). Relationship maintenance strategies on Fortune 500 company web sites. Journal of Communication Management, 10(2), 27-43.

KUVYKAITE, R. \& Piligrimiene, Z. (2013). Communication In Social Media For Company's Image Formation, Economics And Management: 2013. 18 (2), Issn 2029-9338.

MEN, L.R. \& Tsai, W. H. S. (2012). How companies cultivate relationships with publics on social network sites: Evidence from China and the United States, Public Relations Review, 3, 723-730.

ÖZKAYA, M.O. \& Erdem, S. (2009). Kadın girişimcilere yönelik "strateji geliştirmede" yerel yönetimlerle işbirliği içinde olmak, mümkün mü? Journal of Balıkesir University, http://www.bjmer.net/Makaleler/1537125261_5672\%C3\%B6zkaya.pdf (Erişim T: 15 Mayıs, 2014).

SHEN, B. \& Bissell, K. (2013) Social Media, Social Me: A Content Analysis of Beauty Companies' Use of Facebook in Marketing and Branding, Journal of Promotion Management, 19:5, ss. 629-651.

SHIH, C. (2009). The Facebook Era, Indiana, USA: Prentice Hall.

SMITH, B. G. (2010). Socially distributing public relations: Twitter, Haiti, and interactivity in social media. Public Relations Review, 36(4), 329-335.

SMITH, J. (2009). The marketing bible: The guide to marketing your brand, company, product, or service inside facebook. USA: CreateSpace Independent Publishing Platform.

SOYSAL, A. (2010). "Türkiye'de Kadın Girişimciler: Engeller ve Fırsatlar Bağlamında Bir Değerlendirme", Ankara Üniversitesi SBF Dergisi, 65-1, s.83-114.

SWEETSER, K. D. \& Metzgar, E. (2007). Communicating during crisis: Use of blogs as a relationship management tool. Public Relations Review, $33,340-342$.

TNS Global (2013). Türkiye'nin Kadın Omnibus Araştırması. http://yasam.bugun.com.tr/turkiyede-en-cok-kadinlar-kullaniyorhaberi/1051300 (Erişim T: 01.07.2014). 
UFUK, H. \& Özgen, Ö. (2001): “The Profile of Women Entrepreneurs:a Sample From Turkey", International Journal of Consumer Studies, Cilt:25, Say1:4, ss.299-308.

UNGERMAN, O. \& Myslivcova, S. (2014). Model Of Communication Usable For Small And Medium-Sized Companies For The Consumer Communication In Social Media, Trand And Marketing, 168-184.

WATERS, R. D., Burnett, E., Lamm, A. \& Lucas, J. (2009). Engaging stakeholders through social networking: How nonprofit organizations are using Facebook. Public Relations Review, 35(2), ss. 102-106.

WATERS, R. D., Burnett, E., Lamm, A. \& Lucas, J. (2009). Engaging stakeholders through social networking: How nonprofit organizations are using Facebook. Public Relations Review, 35(2), 102-106.

YETIM, N. \& Tatlıdil, E. (2004): "Social and Cultural Dynamics of Women Entrepreneurs: The Case of Small and Medium Size Clothing Entreprises in Adana and Mersin, Turkey, EIMENA ПAI $\triangle E I A \Sigma$, ss.491-507.

YETIM, N. (2002). " Sosyal Sermaye Olarak Kadın Girişimciler: Mersin Örneği",

http://www.onlinedergi.com/MakaleDosyalari/51/PDF2002_2_8.pdf (erişim t. 21.05.2014). 
E. GÖKALİLER, Ö. ALİKILIÇ $\mid 138$ 